\title{
Territory production potential
}

\author{
Natalya Trofimova ${ }^{1, *}$, Elvira Mamleeva ${ }^{1}$, Marina Sazykina $^{1}$, and Gulnara Shiryaeva ${ }^{2}$ \\ ${ }^{1}$ Institute of Strategic Research of the Republic of Bashkortostan, Kirova Str., 15, 450008 Ufa, Russia \\ ${ }^{2}$ Private educational institution of higher education "Eastern Economic and Legal Academy of \\ Humanities", Mendeleeva St., 215/4, 450071 Ufa, Russia
}

\begin{abstract}
Based on the study of theoretical and methodological provisions on the region renewal, quality development and use of the resources, as well as the peculiarities of the regional production process, a methodological approach to the analysis of the potential of fixed assets of municipalities is proposed. The author's approach is based on the analysis of spatial unevenness of distribution, inter-territorial comparison, identification and analysis of the causes of changes caused by natural-geographical, socioeconomic, administrative-territorial and other prevailing conditions. The proposed assessment technique has been tested on the example of municipalities of the Republic of Bashkortostan.
\end{abstract}

\section{Introduction}

The current state of the Russian economy, caused by the impact of sanctions, quarantine measures, as well as the historical features of the development of territories, is characterized by insufficient development rates for its potential. One of the key reasons for the slow growth at the national level is the extremely low resulting values of production activities that have developed over decades in the regions-entities in comparison with the volume of resources spent on their maintenance. All this leads to the fact that the indicators of the efficiency of resource use in the economies of Russian regions lag significantly behind the level of developed countries [1].

In addition to the absence of resource productivity upward trends, an important problem is the disproportions in providing the production process with the resources of the required quantitative and qualitative composition, the unsystematic nature of the processes of renewal, accumulation and consumption of resources within the region, as well as many other theoretical and practical issues requiring deep scientific research.

The above-mentioned issues substantiate the relevance of the study of the potential of territories' fixed assets.

The potential of fixed capital assets (FCA) implies the possibility of using existing equipment and machinery, buildings and structures, transmission and transport vehicles, computers, both involved in the production of goods and services or the performance of work, and existing on the balance sheet of enterprises with the assumption of further use in production. The analysis of their availability, quality, and efficiency of use closely correlates with the assessment of production potential [5]. At the same time, in the general structure of

*Corresponding author: trofimovanv@isi-rb.ru 
the reproductive potential, the potential of fixed assets is included in the element "Accumulated wealth", but according to the principles. Systems of national accounts the construction of the balance of assets and liabilities is carried out according to the element "Fixed assets" separately in the structure of national wealth [1, p. 104].

The structure of fixed capital assets (FCA) depends on the specialization and cooperation of commodity producers, their remoteness from the places of product sales, natural and climatic conditions, the nature and volume of products, the level of mechanization of production processes.

Thus, the purpose of the study is to analyze the renewal, qualitative development and use of the region's resources using the proposed author's approach.

\section{Materials and Methods}

The comparison of FCA potentials between municipalities will be carried out using the proposed author's approach to research through the analysis of quantity-quality-efficiency of use-investment in renewal.

In order to determine the levels of renewal, quality and efficiency of resource consumption in a particular municipality of the Republic of Bashkortostan, the method of comparing the values of each indicator with the average value for the republic is used, as well as using the method of correlation-regression and spatial analysis.

At the next stage, the ranking of municipalities by indicator values will be carried out, the grouping and typology of municipalities of the Republic of Bashkortostan will be constructed depending on the level of use of basic resources.

The developed author's methodology for assessing the characteristics of resource use is based on the definition, grouping and statistical processing of a number of indicators of regional social and economic development.

The analysis of theoretical developments allows us to assert that in domestic and foreign economic science $[2,3,4,7,10,11]$ in assessing the level of renewal of resources, indicators are used that make it possible to judge the volume of investments in a particular resource in order to restore its consumer properties.

Thus, in order to characterize the renewal of fixed assets, the indicator "Investments in fixed assets per 1 ruble of fixed assets, RUB."

In turn, the assessment of the resource quality by most of the examined researchers is based on measuring that part of the total volume of available resources, which is characterized by the greatest return in the economic sense.

To determine the quality of fixed assets, the most informative and adequate indicator is the "Degree of fixed assets depreciation". And, to determine the efficiency of resource consumption, following a number of scientific works by specialists in the field of regional economics, it seems necessary to use a set of indicators that could reliably reflect the return of a resource in the process of its consumption.

First of all, it is necessary to point out that the efficiency of the fixed assets use is quantitatively illustrated by the "return on assets" indicator, calculated per 1 ruble. the cost of fixed assets.

The set of resource renewal indicators considered above, as well as the indicators required for their calculation, are presented in Table 1.

Table 1. Resource renewal indicators, calculation base

\begin{tabular}{|c|c|c|}
\hline \multicolumn{2}{|c|}{ Resource renewal indicators } & Indicators required for calculation \\
\hline \multirow{2}{*}{$\begin{array}{c}\text { Renewal of capital } \\
\text { assets }\end{array}$} & $\begin{array}{c}\text { Investments in fixed } \\
\text { assets per 1 ruble of } \\
\text { fixed assets, RUB }\end{array}$ & $\begin{array}{c}\text { Investments in fixed assets (without investments in residential } \\
\text { property) (in actual prices; million rubles) }\end{array}$ \\
\cline { 3 - 3 } & $\begin{array}{c}\text { Fixed assets value (at the year-end; at full book value; million } \\
\text { rubles) }\end{array}$ \\
\hline
\end{tabular}


Investments in fixed assets per 1 ruble of fixed assets, RUB. is calculated by the ratio of the indicator "Investments in fixed assets" (in actual prices; million rubles), excluding investments in residential property, to the cost of fixed assets (at the year-end; at full book value; million rubles).

In addition to renewal indicators, it is necessary to reflect the sources of resource quality measurement (Table 2).

Table 2. Resource quality indicators, calculation base

\begin{tabular}{|c|c|c|}
\hline \multicolumn{2}{|c|}{ Resource quality indicators } & Indicators required for calculation \\
\hline Fixed assets quality & $\begin{array}{c}\text { Degree of fixed } \\
\text { assets non- } \\
\text { depreciation }\end{array}$ & $\begin{array}{c}\text { Degree of fixed assets depreciation (at the year-end; in } \\
\text { percent) }\end{array}$ \\
\hline
\end{tabular}

The degree of fixed assets non-depreciation is the inverse indicator of the degree of depreciation, i.e. is determined as a deduction from $100 \%$ of the degree of depreciation of fixed assets (at the year-end; in percent).

Methods of calculation and statistical sources of resource consumption efficiency indicators require special attention (Table 3).

Table 3. Resource consumption efficiency indicators, calculation base

\begin{tabular}{|c|c|c|}
\hline \multicolumn{2}{|c|}{$\begin{array}{c}\text { Resource consumption efficiency } \\
\text { indicators }\end{array}$} & Indicators required for calculation \\
\hline \multirow{2}{*}{$\begin{array}{l}\text { Productivity of } \\
\text { fixed assets }\end{array}$} & \multirow{2}{*}{$\begin{array}{l}\text { Return on assets, } \\
\text { rubles per } 1 \text { ruble of } \\
\text { the fixed assets } \\
\text { value }\end{array}$} & Gross Municipal Product, million rubles \\
\hline & & $\begin{array}{c}\text { Fixed assets value (at the year-end; at full book value; million } \\
\text { rubles) }\end{array}$ \\
\hline
\end{tabular}

The capital productivity is calculated by the ratio of indicators "Gross Municipal Product, million rubles" and "Fixed assets value (at the year-end; at full book value; million rubles)".

In order to assess the social and economic development of municipal districts of the Republic of Bashkortostan, the methodology for assessing the "urban product" proposed by the Global Urban Observatory, operating within the UN on human settlements, will be used [9].

Within the framework of this technique, the following method for calculating the GMP is proposed:

$$
G M P_{i}=\frac{G R P_{r}}{N E_{r}} * N E_{i} * \frac{A W_{r}}{A W_{i}},
$$

Where: $\mathrm{GMP}_{\mathrm{i}}$ is the assessment of gross municipal product by the i-municipal district;

GRPr is the Gross Regional Product;

$\mathrm{NE}_{\mathrm{r}}$ is the region number of employed;

$\mathrm{NE}_{\mathrm{i}}$ is the municipal district number of employed;

$\mathrm{AW}_{\mathrm{r}}$ is the average monthly wage by region;

$\mathrm{AW}_{\mathrm{i}}$ is the average monthly wage by the i-municipal district.

Based on the comparison of these indicators, it is possible to determine the characteristics of the region main issues in the field of resource use and its production competencies, to identify potential areas for eliminating imbalances, and, as a result, to formulate a set of forms and methods that can ensure the most intensive use of the main types of resources in the regional economy, taking into account their specific features in a particular region. 


\section{Results and Discussion}

The proposed author's approach "renewal-quality-efficiency" was tested on the example of municipalities of the Republic of Bashkortostan.

The analysis of the provision of the municipal formations of the Republic of Bashkortostan with basic production assets made it possible to identify 4 groups of municipalities.

The first group is represented by large industrial centers of the Republic of Bashkortostan: Ufa, Salavat, Ufa municipal district, Sterlitamak, Uchalinsky municipal district, Blagoveshchensk municipal district, Beloretsk municipal district, Neftekamsk. Despite the decrease in this group share in the total volume of production assets of the republic, it concertizes on its territory more than $85 \%$ of FCA.

The share of the second group of municipalities slightly increased from $2.47 \%$ in 2010 to $4.2 \%$ in 2018 . At the same time, growth was recorded in all municipalities of this group, including municipalities with large industrial enterprises: the municipal districts of Khaibullinsky, Tuimazinsky, Belebeevsky, municipal districts city of Oktyabrsky, city of Kumertau.

The 3rd and 4th groups, including more than $2 / 3$ of the municipal formations of the Republic of Bashkortostan, account for less than $10 \%$ of the main production assets of the Republic of Bashkortostan. These facts testify the high differentiation of municipalities in terms of the provision of FCA as the most important production base.

The important factor in the production process efficiency is the quality of fixed assets. A limited list of statistical data on municipalities makes it possible to include in the system of indicators for assessing the production potential, to characterize the quality of FCA: the share of non-depreciated FCA in the total volume of municipality FCA.

These indicator values for the Republic of Bashkortostan practically did not change throughout the analyzed period. In average, the share of non-depreciated fixed assets in the republic for 2011-2018 exceeded 50\%, with a downward trend, which is a positive fact. But, at the same time, the FCA depreciation level in 20 municipalities of the republic is close to or exceeds $50 \%$, increasing annually. We are talking in particular about the Republic's industrial centers: Sterlitamak region (55.4\% in 2011 and $50.4 \%$ in 2018), Sterlitamak (51.8\% in 2011 and $49.4 \%$ in 2018), Oktyabrsky (52.3\% in 2011 and $48.4 \%$ in 2018), Blagoveshchensky municipal district (59.7\% in 2011 and 47.0\% in 2018), Neftekamsk (59.0 in 2011 to $46.8 \%$ in 2018). The highest increasing degree of fixed production assets depreciation is observed in Ufa.

It shall be noted that in 2011-2018. the leaders among municipalities in terms of the share of non-depreciated FCA were municipalities that do not have a large number of capitalintensive production enterprises on their territory: Blagovarskiy, Karaidelskiy, Burzyanskiy municipal district, Agidel and others. The exception is the Ufa region (67.9\%), Salavat (63.3\%), Khaibulli district (58\%).

At the same time, the most important indicator of the economy and production development is not only the availability and quality of a certain resource, but also the efficiency of its use. Let us analyze the balance of the AEU in the use of production resources, in this case, the use of fixed production assets.

The efficiency indicator of using fixed assets is the return on assets rate [8]. In order to evaluate it, we use the value of the gross municipal product as a generalizing characteristic of the functioning of the municipal formations economy and the cost of fixed assets for the year.

The average capital productivity in the republic decreases annually, which indicates a drop in the efficiency of the use of fixed assets. 
The group of municipal formations with a level of capital productivity above the average for the Republic of Bashkortostan includes municipal formations that specialize in the production of agricultural products mainly in personal subsidiary plots, the provision of tourist services, etc., that is, with a low provision of basic production assets: Davlekanovsky, Kaltasinsky, Baltachevsky, Buzdyaksky, Burzyansky, Kiginsky, Miyakinsky, Buraevsky and other municipal districts. Among the industrially developed municipal and urban formations in 2011, high capital productivity was noted in the city of Kumertau (2740 thousand rubles), Ishimbay municipal district (2703.68 thousand rubles), Belebey municipal district (2525.74 thousand rubles), Sterlitamak municipal district (2282.37 thousand rubles).

By 2018, the trends remained: above the average republican level, capital productivity was recorded in the Ishimbay municipal district (2734 thousand rubles), Ufa (2266 thousand rubles), city of Oktyabrsky, despite a decrease in capital productivity by $11 \%$ to RUB $1,875,000$, retained its place in the first group.

At the same time, due to a sharp decrease in capital productivity, primarily due to the excess of the growth rate of the FCA cost over the volume of the gross municipal product produced, at the end of the rating of the municipalities were: Belebeevsky municipal district (1465 thousand rubles or 58\% of the 2011 level), Sterlitamak district (1409 thousand rubles or $62 \%$ of the 2011 level).

Also, a downward trend in capital productivity was noted in Beloretsk municipal district (1591 thousand rubles in 2011 and 1298 thousand rubles in 2018), Sibay (from 1472 rubles to 1249 rubles), Kumertau (from 2740 thousand rubles up to 1082 rubles).

In the large industrial centers of the republic throughout the analyzed period, an extremely low level of capital productivity was noted: Sterlitamak, Uchalinsky, Blagoveshchensky, Ufa municipal districts, Salavat.

An important role in the formation of the production potential of municipalities is played by investment in the renovation of fixed assets.

In order to analyze the investment activity of municipalities in the field of updating the production base, we use the indicator of the volume of investments in FCA per 1 ruble. basic production assets.

On average in the Republic of Bashkortostan, the reproduction rate of FCA decreased by $27 \%$ from 148.3 rubles in 2010 to 108.3 rubles in 2018 . The dynamics of the indicator was unstable, the growth in 2011-2013 was replaced by a decrease in the crisis period of 2014 .

Among the municipalities, the maximum growth in investments in fixed assets per 1 ruble of fixed assets in 2018 relative to 2011 was shown by the municipalities with a low base of the indicator in the base period: Karaidel district (7.5 rubles), Agidel city (6 rubles), Bakalinsky district (248.7\%), Krasnokamsky district (229\%), Buzdyaksky District (186.3\%), Buraevsky district (156.4\%), Blagoveshchensky district (135.7\%) and Miyakinsky district $(120.4 \%)$

If we consider separately large industrial areas, then they also recorded a positive trend in this indicator. For example, in the Ishimbay district in 2018 compared to 2011, the growth was $80.5 \%$, in the Sterlitamak district $-42.1 \%$, in the city of Ufa $-12.5 \%$, in the Beloretsk district $-10.7 \%$.

A significant decrease in the indicator values under consideration is observed in the Khaibulli district $(-90.2 \%)$, in the Belokataisky district $(-85.1 \%)$, in the Bizhbulyak district $(-81.8 \%)$, in the Askinsky district $(-80.6 \%)$, in the Kuyurgazinsky district $(-77.1 \%)$, in the Kushnarenkovsky district (-74.1\%).

Among the large industrial districts with a significant decrease in investments in fixed assets per 1 ruble of fixed assets, the following municipalities can be distinguished: Uchalinsky district (-57.2\%), Sibay (-55.0\%), Tuimazinsky $(-52.0 \%)$, Ufa district $(-48.6 \%)$, Belebeevsky district (-37.8\%), city of Oktyabrsky (-13.3\%), city of Neftekamsk $(-9.5 \%)$. 
Let us assess the dependence of the change in the use of FCA with the gross municipal product. The data are presented in Table 4.

Table 4. Values of pair correlation coefficient by FCA potential

\begin{tabular}{|c|c|c|c|c|c|c|c|c|}
\hline Indicators & $\mathbf{2 0 1 1}$ & $\mathbf{2 0 1 2}$ & $\mathbf{2 0 1 3}$ & $\mathbf{2 0 1 4}$ & $\mathbf{2 0 1 5}$ & $\mathbf{2 0 1 6}$ & $\mathbf{2 0 1 7}$ & $\mathbf{2 0 1 8}$ \\
\hline Assets/GMP & 0.95 & 0.96 & 0.96 & 0.96 & 0.96 & 0.97 & 0.97 & 0.97 \\
\hline Return on assets/GMP & -0.19 & -0.052 & -0.10 & -0.11 & -0.08 & -0.06 & -0.06 & -0.0013 \\
\hline Capital-labor ratio/GMP & 0.75 & 0.69 & 0.71 & 0.71 & 0.61 & 0.54 & 0.53 & 0.47 \\
\hline
\end{tabular}

The data in Table 4 indicate the extensive development of the economy of the Republic of Bashkortostan, when the volume of the gross municipal product depends primarily on the increase in fixed assets. If in 2011 the contribution of the labor-to-labor ratio in the GMP was $57 \%$ (the coefficient of determination is 0.57 ), then by 2018 it dropped to $22 \%$.

The calculations of the volume, quality, efficiency of use and reproduction of FCA indicators allowed us to identify the following patterns, which are most clearly traced in the example of industrially developed municipalities of the Republic of Bashkortostan. The data are presented in Tables 5-6. Also, the distribution matrices of municipalities were built based on the parameters of volume, quality, efficiency of use and reproduction of FCA.

The leader in using fixed assets efficiency considering their quality and the volume of investments in the renovation is the Ishimbay district. In this Municipal Formation, the highest capital productivity is recorded, with a low share of depreciated FCA and high volumes of investments in the renovation of fixed assets. At the same time, the district has significantly improved its position, moving in terms of capital productivity from 16 to 6 place, in terms of the quality of FCA: from 38 to 12 place, in terms of investments in the renewal of FCA: from 48 to 9 place. However, the production processes in the Ishimbay district in many respects repeat the situation in the Republic of Bashkortostan as a whole, when the growth of investments in capital assets outstrips the growth rates of production volumes, which leads to a decrease in the efficiency of using FCA. Thus, the increase in the volume of investments in 2018 compared to 2011 in the district by $78 \%$, allowed to increase the cost of FCA by $56 \%$ and bring the share of not worn-out funds to $62.1 \%$. However, the capital productivity at the same time in 2018 amounted to only $86 \%$ of the 2011 level.

A similar trend is observed in another industrial center of the Republic of Bashkortostan - Sterlitamak district, with a high share of non-depreciated FCA $(62.8 \%$ and 9 th place in Bashkortostan) and ensuring high growth rates of reproductive processes (153.3 rubles per RUB, RB), capital productivity in 2018 compared to 2011 decreased by $44 \%$. Against the background of the rest of municipal formations of the Republic of Bashkortostan, city of Ufa stands out, which, with a high supply of FCA, demonstrates a consistently high level of capital productivity, having moved in this indicator from 49th place in 2011 to 13th place in 2018.

Table 5. Indicators of volume, quality and efficiency of use of FCA in RB, in 2011

\begin{tabular}{|c|c|c|c|c|c|c|c|c|}
\hline \multicolumn{4}{|c|}{} & \multicolumn{2}{|c|}{ Quality } & \multicolumn{2}{c|}{ Efficiency } & \multicolumn{2}{c|}{ Renewal } \\
\hline $\begin{array}{c}\text { Municipal } \\
\text { Formation }\end{array}$ & $\begin{array}{c}\text { assets, } \\
\text { total, } \\
\text { mln. } \\
\text { RUB }\end{array}$ & $\begin{array}{c}\text { Place } \\
\text { in } \\
\text { RB }\end{array}$ & $\begin{array}{c}\text { Share of } \\
\text { non- } \\
\text { depreciated } \\
\text { fixed } \\
\text { assets, } \%\end{array}$ & $\begin{array}{c}\text { Place } \\
\text { in } \\
\text { RB }\end{array}$ & $\begin{array}{c}\text { Return } \\
\text { on } \\
\text { assets, } \\
\text { thd. } \\
\text { RUB }\end{array}$ & $\begin{array}{c}\text { Place } \\
\text { in } \\
\text { RB }\end{array}$ & $\begin{array}{c}\text { Investments } \\
\text { per 1 ruble } \\
\text { of FCA, } \\
\text { RUB }\end{array}$ & $\begin{array}{c}\text { Place } \\
\text { in } \\
\text { RB }\end{array}$ \\
\hline $\begin{array}{c}\text { Republic of } \\
\text { Bashkortostan }\end{array}$ & 2218.8 & - & 56.6 & - & 2573.78 & - & 159.7 & - \\
\hline City of Ufa & 880663.6 & 1 & 53.2 & 42 & 2149.17 & 49 & 52.6 & 60 \\
\hline City of Salavat & 63534.4 & 2 & 48.0 & 56 & 501.37 & 61 & 120.6 & 36 \\
\hline City of Sterlitamak & 47778.4 & 3 & 57.6 & 28 & 1220.19 & 56 & 67.7 & 56 \\
\hline Ufimsky & 20250.3 & 4 & 65.3 & 6 & 620.33 & 60 & 275 & 5 \\
\hline Uchalinsky & 17816.7 & 5 & 55.7 & 34 & 785.93 & 59 & 168.6 & 17 \\
\hline Blagoveschensky & 17264 & 6 & 51.2 & 49 & 476.29 & 62 & 70.2 & 55
\end{tabular}


Table 5. Continued

\begin{tabular}{|c|c|c|c|c|c|c|c|c|}
\hline City of Neftekamsk & 12904.4 & 7 & 61.9 & 16 & 2453.01 & 35 & 139.1 & 25 \\
\hline City of Sibay & 12510.3 & 8 & 59.0 & 26 & 846.4 & 58 & 135.9 & 28 \\
\hline Beloretsky & 11955.3 & 9 & 72.8 & 1 & 1894.28 & 52 & 64.9 & 57 \\
\hline Tuymazinsky & 8658.2 & 10 & 53.6 & 41 & 2784.44 & 29 & 149.5 & 23 \\
\hline Meleuzovsky & 8563.3 & 11 & 51.8 & 46 & 2450.6 & 36 & 213.6 & 11 \\
\hline City of Oktyabrsky & 7820.4 & 12 & 68.4 & 3 & 2467.81 & 34 & 172.7 & 15 \\
\hline Belebeevsky & 7099.9 & 13 & 55.0 & 37 & 2941.91 & 24 & 122.2 & 35 \\
\hline City of Kumertau & 6697.3 & 14 & 46.9 & 57 & 2093.55 & 50 & 84.6 & 46 \\
\hline Ishymbaysky & 5325.4 & 15 & 54.4 & 38 & 3175.24 & 16 & 83.1 & 48 \\
\hline Sterlitamaksky & 4640 & 16 & 63.6 & 9 & 2376.8 & 40 & 137.8 & 27 \\
\hline
\end{tabular}

Table 6. Indicators of volume, quality and efficiency of use of FCA in RB, in 2018

\begin{tabular}{|c|c|c|c|c|c|c|c|c|}
\hline & & & $\mathbf{Q u}$ & & Effic & acy & Ren & wal \\
\hline $\begin{array}{l}\text { Municipal } \\
\text { Formation }\end{array}$ & $\begin{array}{c}\text { Fixed } \\
\text { assets, } \\
\text { total, } \\
\text { mln. } \\
\text { RUB } \\
\end{array}$ & $\begin{array}{l}\text { Plac } \\
\text { e in } \\
\text { RB }\end{array}$ & $\begin{array}{c}\text { Share of } \\
\text { non- } \\
\text { depreciate } \\
\text { d fixed } \\
\text { assets, \% }\end{array}$ & $\begin{array}{c}\text { Municipa } \\
1 \\
\text { formatio } \\
n\end{array}$ & $\begin{array}{c}\text { Fixed } \\
\text { assets, } \\
\text { total, } \\
\text { mln. } \\
\text { RUB } \\
\end{array}$ & $\begin{array}{l}\text { Plac } \\
\text { e in } \\
\text { RB }\end{array}$ & $\begin{array}{c}\text { Share of } \\
\text { non- } \\
\text { depreciate } \\
\text { d fixed } \\
\text { assets, \% }\end{array}$ & $\begin{array}{c}\text { Municipa } \\
1 \\
\text { formatio } \\
n\end{array}$ \\
\hline $\begin{array}{c}\text { Republic of } \\
\text { Bashkortostan }\end{array}$ & 1735.4 & - & 55.7 & - & $\begin{array}{c}1768.3 \\
3 \\
\end{array}$ & - & 108.3 & - \\
\hline City of Ufa & $\begin{array}{c}1529569 . \\
2\end{array}$ & 1 & 58.1 & 23 & $\begin{array}{c}2266.5 \\
2 \\
\end{array}$ & 13 & 64.3 & 49 \\
\hline City of Salavat & 191702.9 & 2 & 48.3 & 54 & 262.93 & 61 & 83.4 & 39 \\
\hline $\begin{array}{c}\text { City of } \\
\text { Sterlitamak }\end{array}$ & 78440.9 & 4 & 64.4 & 6 & $\begin{array}{c}1044.6 \\
7 \\
\end{array}$ & 55 & 84 & 38 \\
\hline Ufimsky & 83509.1 & 3 & 47.7 & 56 & 210.23 & 62 & 124.7 & 14 \\
\hline Uchalinsky & 35544.2 & 5 & 62.0 & 13 & 584.13 & 56 & 117.2 & 17 \\
\hline $\begin{array}{c}\text { Blagoveschensk } \\
\mathrm{y} \\
\end{array}$ & 30579.5 & 6 & 51.8 & 43 & 449.39 & 59 & 75.5 & 43 \\
\hline $\begin{array}{c}\text { City of } \\
\text { Neftekamsk }\end{array}$ & 25407.7 & 8 & 54.5 & 35 & $\begin{array}{c}1728.2 \\
1\end{array}$ & 31 & 86.8 & 35 \\
\hline City of Sibay & 13211.3 & 14 & 46.8 & 58 & $\begin{array}{c}1249.2 \\
3 \\
\end{array}$ & 51 & 96.9 & 29 \\
\hline Beloretsky & 28122.9 & 7 & 71.4 & 2 & $\begin{array}{c}1297.8 \\
9 \\
\end{array}$ & 50 & 84 & 37 \\
\hline Tuymazinsky & 19697.5 & 10 & 52.1 & 42 & $\begin{array}{c}1670.7 \\
8 \\
\end{array}$ & 35 & 101.6 & 22 \\
\hline Meleuzovsky & 12360.8 & 15 & 49.4 & 51 & $\begin{array}{c}2005.7 \\
3\end{array}$ & 23 & 101.6 & 23 \\
\hline $\begin{array}{c}\text { City of } \\
\text { Oktyabrsky }\end{array}$ & 19563.6 & 11 & 52.9 & 40 & 1875.8 & 27 & 112.1 & 18 \\
\hline Belebeevsky & 19140.1 & 12 & 57.6 & 25 & $\begin{array}{c}1465.0 \\
1 \\
\end{array}$ & 43 & 82.2 & 40 \\
\hline $\begin{array}{c}\text { City of } \\
\text { Kumertau }\end{array}$ & 17905 & 13 & 57.1 & 28 & $\begin{array}{c}1081.9 \\
6 \\
\end{array}$ & 54 & 124.8 & 13 \\
\hline Ishymbaysky & 8326.3 & 19 & 62.1 & 12 & $\begin{array}{c}2734.7 \\
9 \\
\end{array}$ & 6 & 148.6 & 9 \\
\hline Sterlitamaksky & 8220.6 & 20 & 62.8 & 9 & $\begin{array}{c}1409.4 \\
8 \\
\end{array}$ & 45 & 153.3 & 8 \\
\hline
\end{tabular}

In city of Oktyabrsky, with a sufficiently high provision of fixed assets (11th place in the Republic of Bashkortostan in 2018, which is 1 position higher than in 2011), there is a rather low share of non-worn-out fixed assets: 52.9\% (40th place in RB). Compared with 2011, this indicator value decreased from $68.4 \%$ (the decrease was $22.7 \%$ ). At the same time, the return on assets amounted to 1,875.8 thousand rubles. (27th place in the Republic of Bashkortostan), and investments for 1 RUB FCA: 112.1 rubles. (18th place in the Republic of Bashkortostan), which is lower than the values of similar indicators in 2011 by $24.0 \%$ and $35.1 \%$, respectively. 
In the Ufa district in 2018, there was still a high level of provision of fixed assets (3rd place in the Republic of Bashkortostan) and a low level of capital productivity (60th place). At the same time, the value of the indicator characterizing the quality of using the FCA has deteriorated significantly. According to the indicator "The share of not worn-out fixed assets" the region from the 6th position in 2011 dropped to 56th position in $2018(-27.0 \%)$.

In the Uchalinsky district, the situation is as follows. While maintaining positions in the Republic of Bashkortostan in terms of providing fixed assets in 2018 (5th place), capital productivity increased slightly (56th place against 59), which is partly due to the improvement in the quality of FCA. At the same time, during the analyzed period, there was a negative trend of reducing the costs of reproduction of production facilities, by $30.5 \%$ compared to 2011 .

\section{Conclusions}

The conducted study on the basis of the proposed author's approach, through a comparative analysis of the volumes, quality, efficiency of use and costs of restoring fixed production assets, made it possible to identify the following patterns in the production potential of municipalities of the Republic of Bashkortostan in 2011-2018:

- low, with a negative trend, return on assets on average in the Republic of Bashkortostan and in municipal and urban districts, which are large industrial centers;

- concentration of FCA in municipal and urban districts, with low efficiency of their use (Salavat, Sterlitamak, Neftekamsk, Uchalinsky and Blagoveshchensk municipal district, etc.);

- high depreciation of basic production assets at the leading industrial enterprises of the republic;

- a decrease in the volume of investments in fixed assets, on average in the Republic of Bashkortostan by $27 \%$ over the period under review.

Currently, the serious issue is the depreciation of basic production assets, their technological backwardness, assets need not so much repair and reconstruction, but replacement and modernization [6].

In the municipal districts with agricultural specialization, a rather low level of mechanization of production processes is observed. Without technological re-equipment, it will not be possible to ensure high yields and the required production volumes for the transition to sustainable economic development.

It should also be noted the heterogeneity of the republic's municipal formations in terms of the level of production potential, among the reasons: the specialization of the economy, formed in Soviet times, the production base of large enterprises, etc.

Increasing the efficiency of using production potential largely depends on the pace of implementation of innovative technologies: the creation of modern high-tech industries, the use of digital technologies, including in agriculture, which is one of the key sectors in the economy of the republic. At the same time, the speed of investment processes is insufficient to ensure the technological renewal of the production base of the Republic of Bashkortostan.

\section{Acknowledgements}

The study was conducted within the implementation of the Republic of Bashkortostan for young scientists No. 19 GR dd. 03.04.2020. 


\section{References}

1. A.G. Granberg, Economic issues, 9, 15 (2001)

2. M.G. Huseynov, Problems of forecasting, 1, 114 (2007)

3. S.E. Zhelaeva, Economic sciences, 8, 19 (2014)

4. R.M. Kachalov, N.V. Yakovleva, Economy of the region, 4,128 (2014)

5. O.A. Kirillova, Economic sciences, 11, 143 (2011)

6. E.A. Lyaskovskaya, Economic and statistical research of potential, sustainability and development processes: enterprise, industry, region: monograph (2007)

7. G.SMerzlikina. V.V. Kartavchenko, Vestnik VSUIT, 1, 244 (2015)

8. S.N. Rastvortseva, Social space, 1(13), 1 (2018)

9. A.I. Tatarkin, O. A. Kozlova, S. A. Timashev, Security of critical infrastructures and territories, 3(1), 3 (2012)

10. N.V. Arsenieva, L.M. Putyatina, N.V. Tarasova, Economies, 8(3), 73 (2020)

11. O. A. Romanova, Economy of region, 14(3), 806 (2018) 